\title{
TAM as a Model to Understand the Intention of Using a Mobile-Based Cancer Early Detection Learning Application
}

\author{
https://doi.org/10.3991/ijoe.v16i02.12609
}

Hery Harjono Muljo, Bens Pardamean ${ }^{(\varpi)}$, Anzaludin Samsinga Perbangsa, Yulius, Kartika Purwandari, Bharuno Mahesworo, Alam Ahmad Hidayat, Tjeng Wawan Cenggoro

Bina Nusantara University, Jakarta, Indonesia

bpardamean@binus . edu

\begin{abstract}
Technology Acceptance Model (TAM) framework was utilized in this study. Its purpose was to determine the correlation between independent variables consisting of Perceived Ease of Use (PEU), Perceived Usefulness (PU), Attitude toward Using (AU) with dependent variable Behavioral Intention to Use (BIU). Data collection techniques were carried out by distributing questionnaires through group discussion forums. Respondents consisted of medical workers and health cadres both in Jakarta and Yogyakarta. Data were analyzed using correlation test and t-test. The results of the correlation test state that the correlation between PEU and AU is 0.30, which shows a weak correlation. Meanwhile, the correlation of PU and AU is 0.56, PEU and BIU is 0.41 , and PU and BIU is 0.47 , which are considered as moderate correlations. Finally, a strong correlation exists between AU and BIU. T-test results show that the effect of PU on AU is statistically significant with $\mathrm{CI}=95 \%$. Likewise, the effects of PEU on AU, AU towards BIU, PU towards BIU, and PEU towards BIU are significant $(\mathrm{p}<0.05)$.
\end{abstract}

Keywords—Mobile learning, TAM, cancer early detection

\section{Introduction}

The International Agency for Research on Cancer (IARC) estimates that one in five men and one in six women worldwide will suffer cancer during their lifetime. Even one in eight men and one in eleven women will die from the disease. Based on the 2018 International Agency for Research on Cancer (IARC) Globocan data, global cancer has risen to 18.1 million cases. Furthermore, 9.6 million have died from cancer worldwide (see figure 1). 

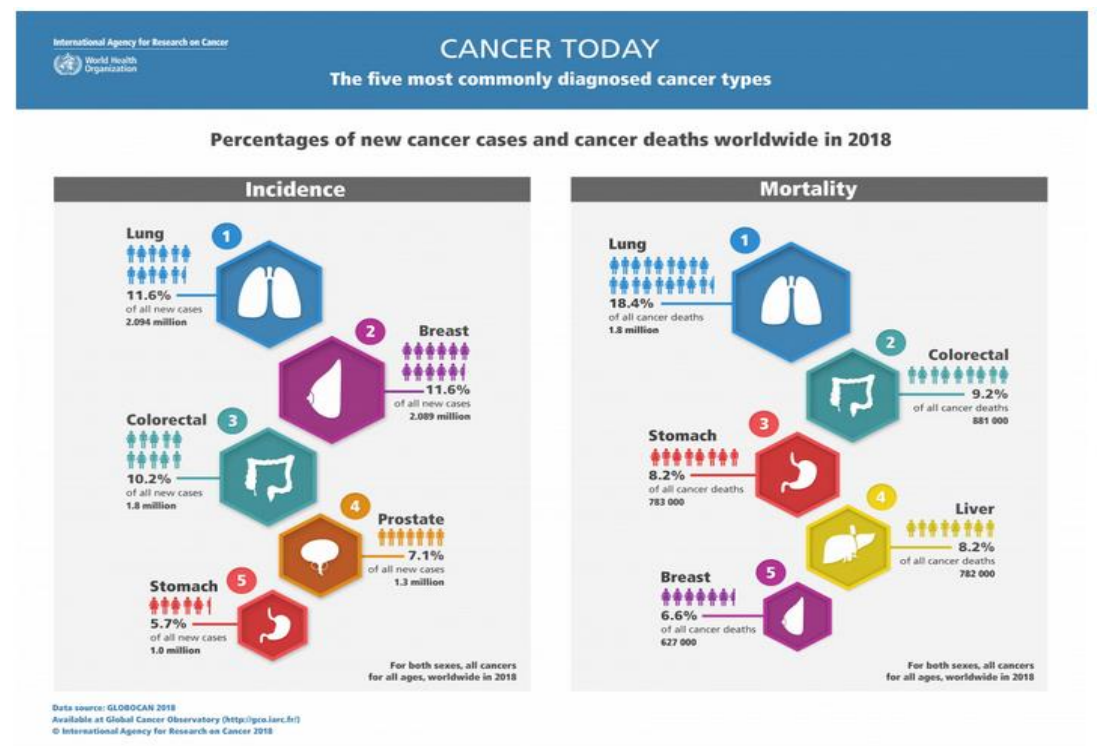

Fig. 1. Cancer Today the Five Most Commonly Diagnosed Cancer Types. (Globocan, IARC 2018)

The incidence of cancer in Indonesia (136.2/100,000 population) ranks 8 th in Southeast Asia, while in Asia ranks 23. The number of new cancer cases in Indonesia is 348,809 cases, with the number of cancer deaths of 207,210 (see figure 2). The low level of knowledge and understanding is one of the factors that cause patients to delay early detection [1].

A series of efforts have been made by the Government of Indonesia to reduce the number of people living with cancer, including counseling and formal training. However, this effort requires a lot of money [2]. Also, the Government of Indonesia, through the Ministry of Health, created an early detection program for breast cancer and cervical cancer. Women aged 30-50 years can use clinical breast examination methods and visual inspection with acetic acid (IVA test) for the cervix. Another program is breast self-examination by examining her breasts by looking and feeling with fingers to detect whether there are lumps in her breasts [3], as well as developing early cancer discovery programs in children, cancer palliative services, early detection of lung cancer risk factors, and national cancer registration system.

The spread of early breast and cervical cancer detection programs can also be through community-based network organizations [4] by empowering health activists to help underserved individuals to get regular and quality health care [5]. The series of efforts turned out not to be able to reach remote areas optimally and requires a new step to provide broader services. 


\begin{tabular}{|c|c|c|c|}
\hline \multicolumn{4}{|c|}{$\begin{array}{l}\text { Summary Statistic } 2018 \text { (Indonesia) } \\
\text { Number of new cases, Number of deaths, Number of prevalent cases (5-year) }\end{array}$} \\
\hline & Males & Females & Both sexes \\
\hline Population & 134273304 & 132521684 & 266794986 \\
\hline Number of new cancer cases & 160578 & 188231 & 348809 \\
\hline Age-standardized incidence rate (World) & 134.8 & 139.6 & 136.2 \\
\hline Risk of developing cancer before the age of 75 years (\%) & 14.5 & 14.3 & 14.3 \\
\hline Number of cancer deaths & 108186 & 99024 & 207210 \\
\hline Age-standardized mortality rate (World) & 94.2 & 76.1 & 84.1 \\
\hline Risk of dying from cancer before the age of 75 years $(\%)$ & 10.0 & 8.2 & 9.1 \\
\hline 5-year prevalent cases & 308850 & 466270 & 775120 \\
\hline $\begin{array}{l}\text { Top } 5 \text { most frequent cancers excluding non-melanoma skin cancer } \\
\text { (ranked by cases) }\end{array}$ & $\begin{array}{r}\text { Lung } \\
\text { Colorectum } \\
\text { Liver } \\
\text { Nasopharynx } \\
\text { Prostate }\end{array}$ & $\begin{array}{r}\text { Breast } \\
\text { Cervix uteri } \\
\text { Ovary } \\
\text { Colorectum } \\
\text { Thyroid }\end{array}$ & $\begin{array}{r}\text { Breast } \\
\text { Cervix uteri } \\
\text { Lung } \\
\text { Colorectum } \\
\text { Liver }\end{array}$ \\
\hline
\end{tabular}

Fig. 2. Number of new cases, Number of deaths, Number of prevalent cases in 5-year (The Global Cancer Observatory, 2019)

Online-based learning, or known as online learning to detect cancer, is the first step ever developed to answer the challenges above [6]. As technology advances, mobilebased cancer detection learning is developed, which is a continuation of this research.

Benchmarks used to determine, explain, and predict the level of acceptance of mobile learning applications by users is to use the Technology Acceptance Model (TAM) method [7]. This study aims to determine the correlation between independent variables, namely Perceived Ease of Use (PEU), Perceived Usefulness (PU), Attitude toward Using (AU), and dependent variables, namely Behavioral Intention to Use (BIU), and also to find out how the influence of independent variables on the dependent variable.

\section{Literature Review}

\subsection{Mobile learning}

Mobile learning is the intersection of mobile computing and e-learning [8]. The spread of the use of mobile devices as the first learning process occurred in the mid1990s [9], which was very helpful in accessing and disseminating information [10]. Mobile learning is utilizing educational technology devices such as laptops, digital personal assistants (PDAs) [16], tablets, cell phones, and e-book reader applications. The devices allow users to use mobile learning anytime and anywhere [11]. A study in Guangzhou showed that the students agreed to use mobile devices because they could study outside of school rather than having to be present in the classroom [14].

Many researchers agreed that mobile learning provides many benefits in enhancing creativity, collaboration, and communication in the teaching and learning process 
[12]. Furthermore, mobile learning also greatly helps teachers in distributing modules or materials to be taught every day. Mobile learning also helps teachers to interact in the process of teaching and learning online, so they do not always have to meet their students face to face [13]. Thus mobile learning can overcome the problem of distance in transferring knowledge between teacher and student.

Despite having many of these advantages, there are also disadvantages of using mobile learning. Among others is the dependence on the Internet and electricity network reliability. This dependency can hamper the usage of mobile learning because not everyone has an adequate Internet and electricity network [15]. Besides, the problem of social interaction is also minimal when using mobile learning due to the lack of direct meetings between instructors and students [17].

\subsection{Technology acceptance model}

TAM (Technology Acceptance Model) was first implemented by Davis in 1989 [7], which is a model for analyzing the acceptance factors of an information system and technology from users [18]. TAM can be used to analyze the habits of students in using e-learning [19].

The original TAM model includes 4 variables that measure an information system, namely Perceived Usefulness (PU), Perceived Ease of Use (PEU), Behavioral Intention to Use (BIU), and Attitude toward Using (AU). Perceived Ease of Use (PEU) is the main factor of the acceptance of an information system [20]. Perceived Usefulness (PU) is a factor used where the person believes that an information system can improve performance in work [21].

\subsection{Effects of perceived usefulness (PU) on attitude toward using (AU)}

Pro or contra attitude toward the application of information systems is influenced by the level of one's confidence in the utilization of the system [24]. The higher the usefulness felt by the user when using a system or technology, the more positive the user's attitude towards the use of the technology. A study of the factors that influence the intention to use Mobile Payment states that perceived usefulness is positively related and significantly influences attitude toward using [22]. Likewise, other research related to determinants of mobile learning adoption, states that perceived usefulness is positively related and significantly influences attitude toward using [23]. Therefore, the first research hypothesis is:

H1: Perceived Usefulness (PU) influences Attitude toward Using (AU)

\subsection{Effect of perceived ease to use (PEU) on attitude toward using (AU)}

The ease of use influence the pros or cons attitude towards the information systems [24]. Perceived Usefulness is a phase where someone believes that using an information system will increase productivity, performance, work performance, and bring benefits for those who use it [7][25]. Someone who will use information technology has an understanding of its usefulness [26], which results in the ease of 
use. A study comparing the factors that influence e-commerce adoption shows that PEU has a positive effect on AU [27]. Whereas in other studies related to online shopping on Instagram, shows that the user has proven and felt the benefits [28]. Based on the results of the study, the second hypothesis is:

H2: Perceived Ease of Use (PEU) influences Attitude toward Using (AU).

\subsection{Effect of attitude toward using (AU) on behavior intention to use (BIU)}

Attitudes and subjective norms influence the intention of human behavior [29]. If someone tends to have a positive attitude towards technology, then that person tends to accept and use the technology, or vice versa [24]. One study related to factors influencing student adoption and the use of e-learning shows the results that attitude towards the use of mobile learning influence the intention to use [30]. Attitude toward Using (AU) is also obvious in the use of internal banking systems because it makes it easier to use technology. That increases the interest of users to use technology in their work [31]. The most dominant intention is influenced by attitude because Attitude toward Using (AU) is a strong mediator between belief and interest to use [32]. Based on the results of the study, the third hypothesis is:

H3: Attitude toward Using (AU) influences Behavior Intention to Use (BIU).

\subsection{Effect of perceived usefulness (PU) on behavior intention to use (BIU)}

Behavioral intention to use is the tendency for a person's behavior to continue to apply the technology, including the desire to keep using it and to influence other users [7]. Increased user interest in the system is seen when the usefulness of the system has been felt [33]. One researcher who examined mobile services has proven that perceived usefulness is one of the factors supporting the intention of users to use technology [34]. The use of technology by users shows that the level of user confidence in the method of delivering information is beneficial and is considered as a choice [35]. Thus, positively perceived usefulness will directly affect intention to use [36]. Based on the results of the research, the fourth hypothesis is:

H4: Perceived Usefulness (PU) influences Behavior Intention to Use (BIU)

\subsection{Effect of perceived ease of use (PEU) on behavior intention to use (BIU)}

Behavioral intention to use is a form of one's belief in the use of technology accompanied by increased interest in using it, and finally using information technology to complete the work [37]. The higher one's perception of the ease of using the system, the higher the level of utilization [38]. This means that when the user believes that the information system is easy to use, the user will use it or vice versa [39]. Several previous studies have mentioned that perceived ease of use has a positive effect on the attitude of technology use [40] and [41]. Based on the results of the research, the fifth hypothesis is:

H5: Perceived Ease of Use (PEU) influences Behavior Intention to Use (BIU) 


\section{Result and Discussion}

\subsection{Correlation Test}

The correlation tests between variables are shown in figure 3. AU and BIU shows the strongest correlation $(\rho=0.64)$, compared to other correlations. Correlation test between PU and AU; and correlation test between PU and BIU also gave strong correlation score with $\rho=0.57$ and $\rho=0.48$ respectively, which can be classified as moderate correlation. Lastly, the correlation related to PEU shows the weakest correlation among other correlations. Even though AU has strong correlation with PU and BIU, it has weak correlation of $\rho=0.3$ with PEU.

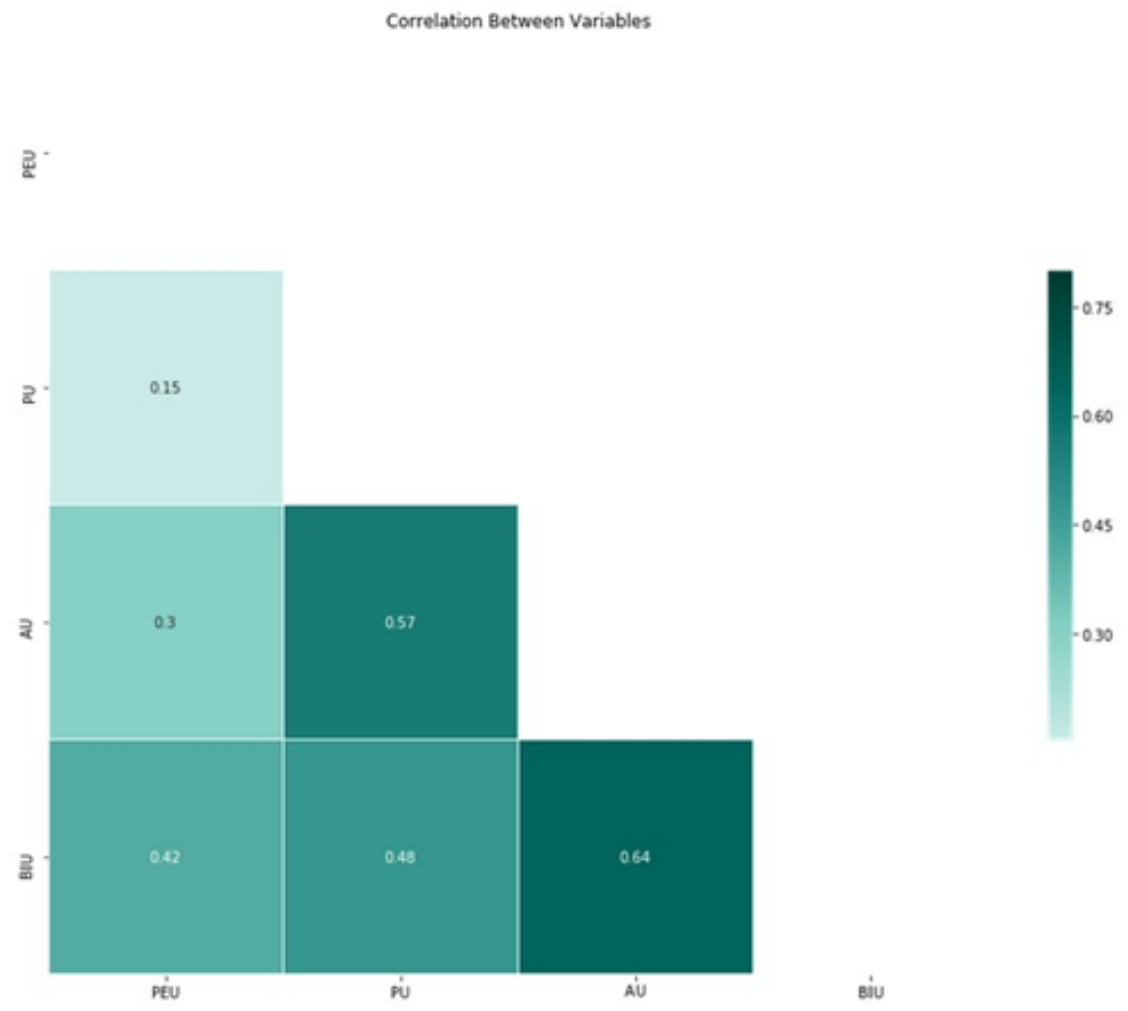

Fig. 3. Correlation between Variables

\subsection{Hypothesis test}

Linear regression explains the pattern of relationships between two or more variables. The results of this analysis determine whether between the variables being studied against the relationship, influence each other, and how much the level of 
relationship. The results of testing the hypothesis using linear regression can be seen in figure 4.

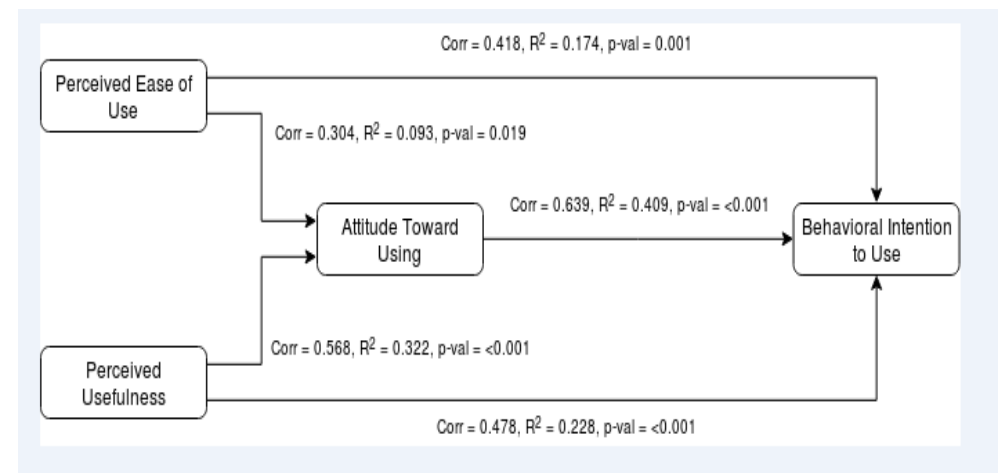

Fig. 4. Linear Regression Analysis Result

\section{- Hypothesis 1 Testing}

The linear regression model shows the relationship between PU to AU based on the data collected as follow:

$$
\mathrm{AU}=1.1911+0.5750 * \mathrm{PU}+\varepsilon
$$

This linear regression model explains that there is a positive influence between PU on AU. The slope value of 0.5750 can be interpreted as an increase in the average perception of utilization due to an increase in attitude towards use. T-test result indicates that the effect of PU is statistically significant at $\alpha=0.05$ ( $p<0.001)$. Thus the $\mathrm{H} 1$ hypothesis is proven that PU influences AU.

The regression line shown in figure 5 depicts the relationship between PU and AU.

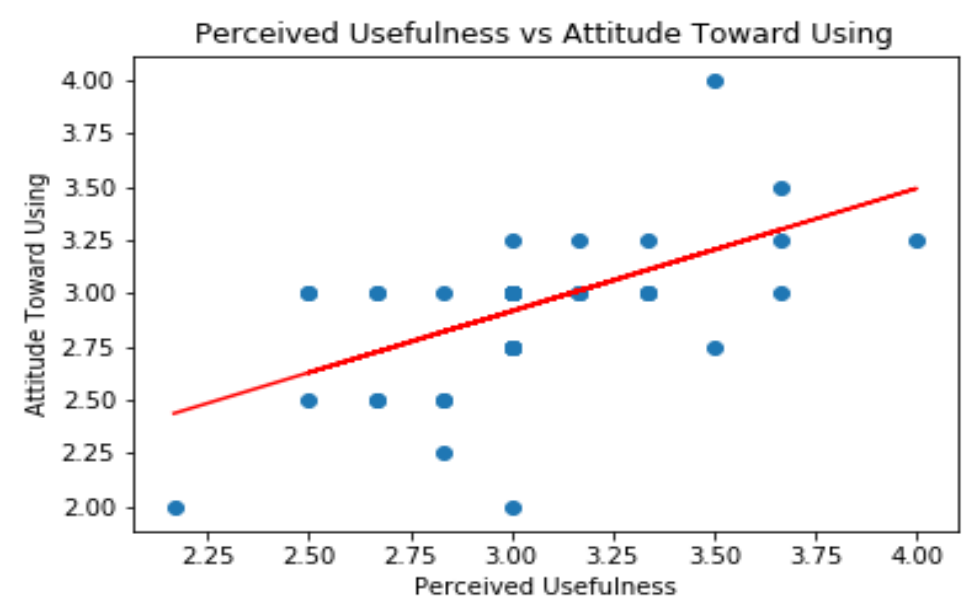

Fig. 5. Regression Plot between Perceived Usefulness (PU) of Attitude toward Using (AU) 
As given by the fitted linear model, the R2 of the linear model in figure 5 is 0.322 . This means that only $32.2 \%$ of the variability in AU can be explained by the variability in PU.

\section{- Hypothesis Testing 2}

The linear regression model also found relationship between PEU and AU based on the data collected is:

$$
\mathrm{AU}=2.0832+0.2976 * \mathrm{PEU}+\varepsilon
$$

This linear regression model explains the positive effect on PEU between AU. It is possible to interpret the estimated slope value of 0.2976 as an increase in the PEU due to an increase in AU. T-test result shows a statistically significant effect of PEU at $\alpha=$ 0.05 ( $\mathrm{p}=0.019)$, so the $\mathrm{H} 2$ hypothesis is proven to affect the AU.

The following line of regression describes the relationship between PEU and AU (figure 6).

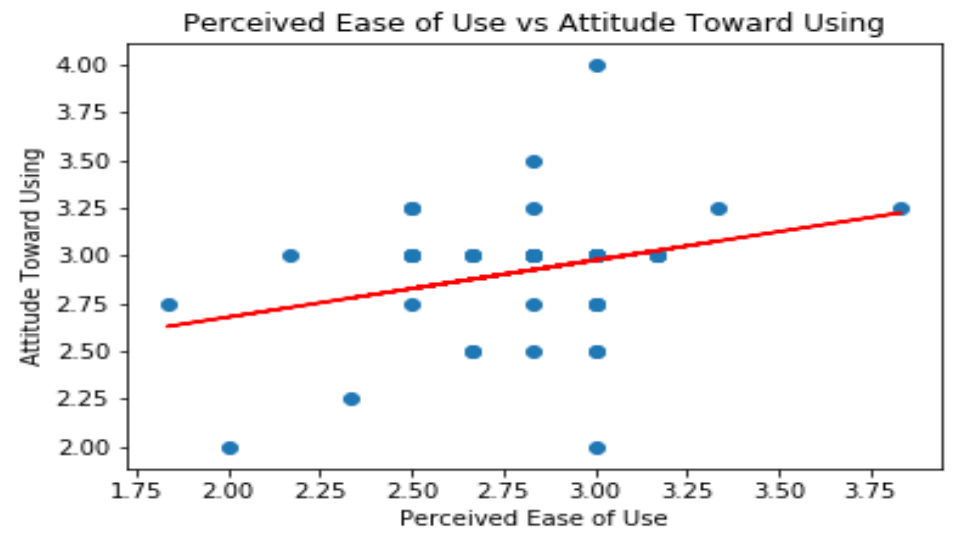

Fig. 6. Regression Plot between Perceived Ease of Use (PEU) and Attitude toward Using (AU)

Based on the linear model figure 6, the R-squared value is 0.093 . This means that the variation in PEU will explain $9.3 \%$ of the variability in AU.

\section{- Hypothesis Testing 3}

The results of the analysis show that the linear regression model that showing the correlation between AU to BIU based on sample data is:

$$
\mathrm{BIU}=0.5033+0.7879 * \mathrm{AU}+\varepsilon
$$

This linear regression model explains that the $\mathrm{AU}$ and $\mathrm{BIU}$ has a positive influence. The reported slope value of 0.7879 can be interpreted as an increase in the $\mathrm{AU}$ due to an increase in BIU. T-test result shows a statistically significant effect at $\alpha$ 
$=0.05$. This is shown by the p-value magnitude that is much smaller than 0.001 . Therefore, the $\mathrm{H} 3$ hypothesis is proven.

The following regression line explains the relationship between $\mathrm{AU}$ and BIU (figure 7).

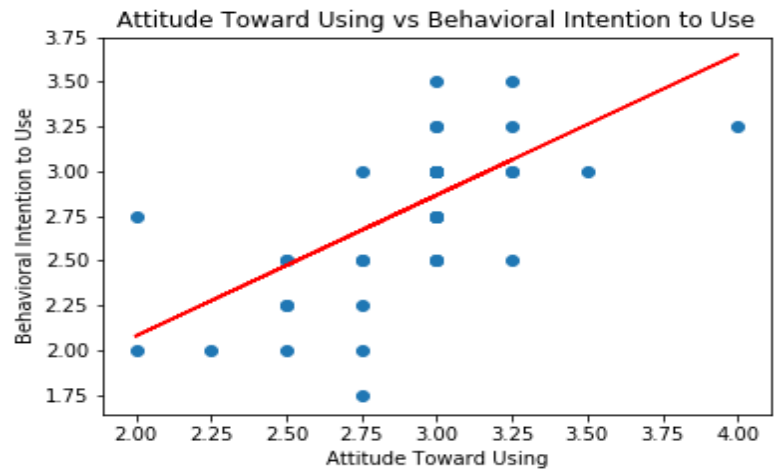

Fig. 7. Regression Plot between Attitude toward Using (AU) and Behavior Intention to Use (BIU)

As inferred from the linear model in figure 7 , the R-squared value is 0.409 , that means only $40.9 \%$ of the variability in AU will be stated by the BIU variation.

\section{- Hypothesis Testing 4}

A linear regression analysis is again adopted to find a relation between between PU and BIU, which is found to be:

$$
\mathrm{BIU}=1.0076+0.5964 * \mathrm{PU}+\varepsilon
$$

The model is visualized on the data set in figure 8 and has R2 value of 0.5964 . Ttest demonstrates that the effect of PU on BIU is statistically significant at $\alpha=0.05$ (p-value < 0.001), implying the H4 hypothesis is accepted.

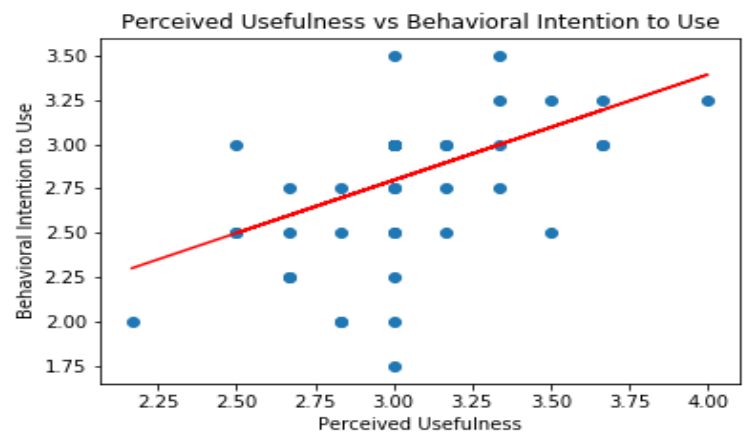

Fig. 8. Regression Plot between Perceived Usefulness (PU) and Behavior Intention to Use (BIU) 


\section{- Hypothesis Testing 5}

Assuming a linear regression model between PEU and BIU (figure 9), the resulting equation can be written as:

$$
\mathrm{BIU}=1.3767+0.5036 * \mathrm{PEU}+\varepsilon,
$$

Where the value of $\mathrm{R} 2$ is 0.174 . The t-test result demonstrates a statistically significant relation between the two variables with $\mathrm{p}$-value of 0.001 . The result firmly implies that $\mathrm{H} 5$ hypothesis is accepted.

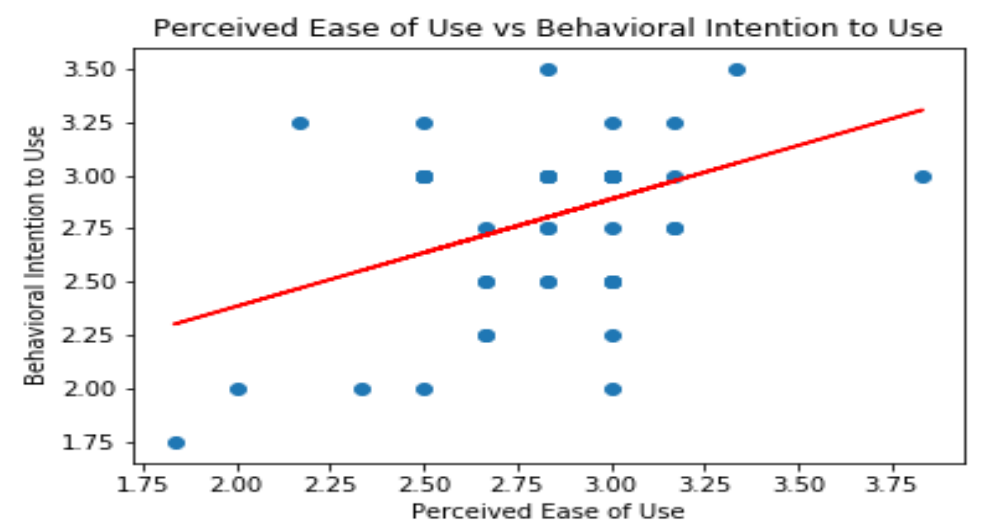

Fig. 9. Regression Plot between Perceived Ease of Use (PEU) and Behavior Intention to Use (BIU)

\section{Conclusion}

The correlation test that produces a low correlation is found in the correlation between PEU and $\mathrm{AU}$, which is equal to 0.30 . The correlation test that produces a moderate correlation is found in the correlation between PU and AU of 0.56, PEU and BIU of 0.41 and PU and BIU of 0.47. Finally, the correlation test that produces a strong correlation is found in the correlation between AU and BIU of 0.63 .

Based on the results of the t-test showed that the effect of perceived usefulness on attitude toward using was statistically significant at $\alpha=0.05$. Likewise, the effect of PEU on AU, AU towards BIU, PU towards BIU, and PEU towards BIU are significant $(\mathrm{p}<0.05)$.

\section{$5 \quad$ References}

[1] Dyanti G.A.R., Suariyani N.L.P. (2016). Faktor-Faktor Keterlambatan Penderita Kanker Payudara Dalam Melakukan Pemeriksaan Awal Ke Pelayanan Kesehatan. Jurnal Kesehatan Masyarakat. Vol 11(2), pp96-104. https://doi.org/10.15294/kemas.v11i2.3742 
[2] Muljo, H.H., Perbangsa, A.S., Pardamean, B. (2019). Assessment of Online Learning Application for Health Education. International Journal of Online and Biomedical Engineering. Vol 15(12), pp 69-80. https://doi.org/10.3991/ijoe.v15i12.11157

[3] Setiati, E., 2009. Waspadai Empat Kanker Ganas Pembunuh Wanita, Kanker Rahim, Kanker Indung Telur, Kanker Leher Rahim, Kanker Payudara. Yokyakarta: Andi. https:// doi.org/10.18860/sains.v0i0.1862

[4] Fernández, M. E., DeBor, M., Candreia, JD. M. (2010). Dissemination of a breast and cervical cancer early detection program through a network of community-based organizations. Health Promotion Practice. Vol. 11(5), pp 654-664. https://doi.org/10.1 $177 / 1524839908325064$.

[5] Ngoc Nguyen, T.-U., Tanjasiri, S. P., Kagawa-Singer, M., Tran, J. H., \& Foo, M. A. (2008). Community Health Navigators for Breast- and Cervical-Cancer Screening Among Cambodian and Laotian Women: Intervention Strategies and Relationship-Building Processes. Health Promotion Practice, 9(4), 356-367. https://doi.org/10.11 $\underline{77 / 1524839906290251}$

[6] Muljo, H.H., Pardamean, B. Perbangsa, A.S. (2017). The implementation of online learning for early detection of cervical cancer. Journal of Computer Science. Vol 13 (11). pp 600-607. https://doi.org/10.3844/jcssp.2017.600.607

[7] Davis, F. D., (1989). "Perceived Usefullness, Perceived Ease of Use, and User Acceptance of Information Technology”, MIS Quarterly, vol. 13, no.3. https://doi.org/10.2307/249008

[8] Quinn, C. (2000). mLearning. Mobile, Wireless, In-Your-Pocket Learning. Linezine. Fall 2000.

[9] Korkmaz, Ozgen. (2015). New Trends on Mobile Learning in The Light of Recent Studies, Participatory Educational Research (PER), vol 2(1), pp. 1-10.

[10] Foti, Megan. K. (2014). Mobile Learning: How Students Use Mobile Devices to Support Learning, Journal of Literacy and Technology, Vol 15, pp. 58-78.

[11] Sung, Y.T., Chang, K.E., Liu, T.C. (2016). The effects of integrating mobile devices with teaching and learning on students' learning performance: A meta-analysis and research synthesis. Computers \& Education, Vol. 94, pp. 252-275. https://doi.org/10.10 16/j.compedu.2015.11.008

[12] Alhajri, Rana. (2016). Prospects and Challenges of Mobile Learning Implementation: A Case Study. Journal of Information Technology \& Software Engineering, Vol. 6, pp. 1-8.

[13] Limtrairut, Pakapan., Marshall, Stuart., Andreae, Peter., Know the Mobile Learning Application Users, 2016, International Conference on Computer Supported Education, 2, pp. 378-387. https://doi.org/10.5220/0005791303780387

[14] Wong, Hugo Chun-hung (2014). A study of mobile learning for higher education students in Guangzhou, 2014, SpringerPlus, 3, pp. 1-2.

[15] Corlett, Dan., Sharples, Mike., Bull, Susan., Chan, Tony. (2005). Evaluation of a mobile learning organizer for university students. Journal of Computer Assisted learning. Vol. 21, pp. 162-170. https://doi.org/10.1111/j.1365-2729.2005.00124.x

[16] Hussin, Supyan., Manap, Mohd Radzi., Amir, Zaini., Krish, Pramela. (2012). Mobile Learning Readiness among Malysian Students at Higher Learning Institutes. Asian Social Science. vol. 8, pp. 276-283. https://doi.org/10.5539/ass.v8n12p276

[17] Alharbi, Saleh., Drew, Steve. (2014). Mobile Learning-system usage: Scale development and empirica test. International Journal of Advanced Research in Artificial Intelligence, 3, pp. 31-47.

[18] Surendran, Priyanka. (2012). Technology Acceptance Model: A Survey of Literature. International Journal of Business and Social Research. Vol. 2, pp. 175-178. 
[19] Lee, Younghwa., Kozar, Kenneth A., Larsen, Kai R.T. (2003). The Technology Acceptance Model: Past, Present, and Future. Communications of the Association for Information Systems. Vol. 12, pp. 752-780. https://doi.org/10.17705/1cais.01250

[20] Pikkarainen, Tero., Pikkarainen, Kari., Karjaluoto, Heikki., Pahnila, Seppo. (2004). Consumer acceptance of online banking: an extension of the technology acceptance model. Internet Research. Vol 14, pp. 224-235. https://doi.org/10.1108/10662240410542652

[21] Venkatesh, Viswanath., Davis, Fred D. (2000). A Theoretical Extension of the Technology Acceptance Model: Four Longitudinal Field Studies. Vol. 46, pp. 186-204. https://doi.org/10.1287/mnsc.46.2.186.11926

[22] Kim, C., Mirusmonov, M., \& Lee, I. (2010). An empirical examination of factors influencing the intention to use mobile payment. Computers in Human Behavior, Vol. 26(3), 310-322. https://doi.org/10.1016/j.chb.2009.10.013

[23] Tan, G.W., Ooi, K. Sim, J., dan Phusavat, K. (2012). Determinants of Mobile Learning Adoption: an Empirical Analysis. Journal of Computer Information Systems, Vol 52(3). pp. 82-91.

[24] Chen, L., Gillenson, M.L. and Sherrell, D.L. (2002), "Enticing online consumers: an extended technology acceptance perspective", Information \& Management, Vol. 39, pp. 705-19. https://doi.org/10.1016/s0378-7206(01)00127-6

[25] Wibowo, Arif. 2006. Kajian Tentang Perilaku Pengguna Sistem Informasi Dengan Pendekatan Technology Acceptance Model (TAM). Jakarta Selatan : Program Studi Sistem Informasi, Fakultas Teknologi Informasi Universitas Budi Luhur. https://doi.org/10.22441/fifo.v8i1.1298

[26] Thompson, Ronald L, Haggings, Christoper A., dan Howell, Jane M. (1991), "Personal Computing: Toward a Conceptual Model of Utilization”, Mis Quarterly, pp.125-143. https ://doi.org/10.2307/249443

[27] Yu, J., I. Ha, M. Choi and J. Rho. (2005). Extending the TAM for a t-commerce. Information \& Management, Vol.42 (7) pp 965-976. https://doi.org/10.1 016/j.im.2004.11.001

[28] Wida, M.W., Yasa, N.N.K., Sukaatmadja, I.P.G. (2016). Aplikasi Model Tam (Technology Acceptance Model) pada Perilaku Pengguna Instagram Putu Ayu. Jurnal Ilmu Manajemen Mahasaraswati vol. 6(2).

[29] Wu, K., Zhao, Y., Zhu, Q. Zheng, H., (2011) A meta-analysis of the impact of trust on technology acceptance model: Investigation of moderating influence of subject and context type. International Journal of Information Management 31(6) pp 572-581. DOI: 10.1016/j.ijinfomgt.2011.03.004. https://doi.org/10.1016/j.ijinfomgt.2011.03.004

[30] Park, S.Y., Nam, M.W., Cha, S.B., 2011. University students' behavioral intention to use mobile learning: evaluating the technology acceptance model. Br. J.Educ. Technol. 43 (4), 592-605. https://doi.org/10.1111/j.1467-8535.2011.01229.x

[31] Nugraha, A., Laksito, H. (2014). Anteseden Penerimaan Teknologi Informasi dalam Profesi Audit Internal dengan Menggunakan Technology Acceptance Model (Studi Empiris pada Bank Perkreditan Rakyat di Jawa Tengah). Diponegoro Journal of Accounting. Vol. 3(2): pp. 1-15

[32] Heijden, H.V.D., Verhagen, T., and Creemers, M. (2003). Understanding online purchase intentions: contributions from technology and trust perspectives. European Journal of Information Systems Vol. 12 pp. 41-48. https://doi.org/10.1057/palgrave.ejis.3000445

[33] Yusoff, Mohd, Y., Muhammad, Z., Pasah.E.S. dan Robert, E. (2009). Individual Differences, Perceived Ease of Use, and Perceived Usefulness in the Elibrary Usage, Computer and Information Science, Vol. 2(1), pp. 76-83. https://doi.org/10.5 $\underline{539 / \text { cis.v2n1p76 }}$ 
[34] Nysveen, H.; Pedersen, P.; dan Thorbjornsen, H. 2005b. Intentions to use mobile services: Antecedents and cross-service comparisons. Journal of Academy of Marketing Science. 33(3). Pp 330-346. https://doi.org/10.1177/0092070305276149

[35] Walker, R.H., dan Johnson, L.W. (2006). Why Consumer Use and Do Not Use Technology-Enabled. Journal of Service Marketing, Vol. 20( 2), pp. 125- 135.

[36] Henderson, R., and Divett, M.J. (2003). Perceived usefulness, ease of use and electronic supermarket use, International Journal Human-Computer Studies, Vol. 59, pp. 383- 395. https://doi.org/10.1016/s1071-5819(03)00079-x

[37] Venkatesh, V., Thong, J.Y.L., Xu, X. (2012). Consumer Acceptance And Use Of Information Technology: Extending The Unified Theory Of Acceptance And Use Of Technology. MIS Quarterly. Vol. 36(1), pp. 157-178. https://doi.org/10.2307/41410412

[38] Igbaria, M., Anandarajan, M., dan Anakwe, U. (2000). "Technology acceptance in the banking industry: A perspective from a less developed country," Information Technology and People, MCB University Press, pp. 298-3 12. https://doi.org/10.11 $\underline{08 / 09593840010359491}$

[39] Jogiyanto. 2007. Sistem Informasi Keperilakuan. Yogyakarta: Penerbit Andi.

[40] Suh, B., and Han, I. (2002) Effect of Trust on CustomerAcceptance of Internet Banking. ElectronicCommerceResearchand Applications, Vol. 1, pp. 247-263.

[41] Shih, Y. and Fang, K. (2004) The Use of a Decomposed Theory of Planned Behavior to Study Internet Banking in Taiwan. Internet Research, Vol 14, No 3, pp 213-223. https://doi.org/10.1108/10662240410542643

\section{Authors}

Hery Harjono Muljo is a researcher at Bioinformatics \& Data Science Research Center and a lecturer at Accounting Program, Bina Nusantara University, Jakarta, Indonesia. His research expertise is in developing management information system of health institutions such as hospitals and clinics.

Bens Pardamean is Director of Bioinformatics \& Data Science Research Center and Associate Professor of Computer Science, Bina Nusantara University, Jakarta, Indonesia. His research expertise is in information technology, bioinformatics, and education, including a strong background in database systems, computer networks, and quantitative research.

Anzaludin Samsinga Perbangsa is a researcher at Bioinformatics \& Data Science Research Center and a lecturer at School of Information Systems, Bina Nusantara University, Jakarta, Indonesia. His research expertise is in developing tools to investigate the interplay of genetic and environmental factors in agriculture and has developed agricultural germplasm database.

Yulius is a researcher at Bioinformatics \& Data Science Research Center and a lecturer at School of Information Systems, Jakarta, Indonesia. His current research interest is focused on developing tools and strategies with IT solution to face global IT trends.

Kartika Purwandari is a research assistant at Bioinformatics \& Data Science Reserach Center. Her current research interest is focused on implementing and developing system based on artificial intelligence. 
Bharuno Mahesworo is a research assistant at Bioinformatics \& Data Science Reserach Center. His current research interest is focused bioinformatics and data science.

Alam Ahmad Hidayat is a research assistant at Bioinformatics \& Data Science Research Center, Bina Nusantara University, Jakarta, Indonesia. His research interests are in the areas of biostatistics and also the applications of machine learning.

Tjeng Wawan Cenggoro is a researcher of the Bioinformatics \& Data Science Research Center (BDSRC), as well as a faculty member of School of Computer Science, Bina Nusantara University. His research focus is the application and development of artificial intelligence for bioinformatics.

Article submitted 2019-11-03. Resubmitted 2019-12-07. Final acceptance 2019-12-08. Final version published as submitted by the authors. 